\title{
A Brief Overview of Hyperthermia in Cancer Treatment
}

\author{
Gianfranco Baronzio ${ }^{1 *}$, Gurdev Parmar ${ }^{2}$, Marco Ballerini ${ }^{1}$, Andras Szasz ${ }^{3}$, Miriam Baronzio ${ }^{1}$ and Valter Cassutti ${ }^{1}$ \\ ${ }^{1}$ Demetra ML Center, for Clinical Hyperthermia and Immunity, Terni, Italy \\ ${ }^{2}$ Integrated Health Clinic, Fort Langley, B.C., Canada \\ ${ }^{3}$ St. Istvan University, Gödöllö, Hungary
}

"Corresponding author: Baronzio Gianfranco, Scientific Director of Demetra ML Cell Factory and Hyperthermia /Immunity Center, Via Cassian Bon 1/A, 05100 Terni, Italy, Tel/Fax: +39-331 881712, E-mail: barongf@intercom.it

Rec date: Apr 22, 2014, Acc date: May 15, 2014, Pub date: June 1, 2014

Copyright: ( 2014 Baronzio G, et al. This is an open-access article distributed under the terms of the Creative Commons Attribution License, which permits unrestricted use, distribution, and reproduction in any medium, provided the original author and source are credited.

\begin{abstract}
Despite the large economic and intellectual efforts, cancer is still not easily treatable disease by conventional therapies. This led ultimately to reconsider hyperthermia, like one of interesting treatment methods connected to immunity and tumor metabolism. Hyperthermia has also the ability to play an additional role when used together with the conventional methods of treatment: surgery, radiotherapy, chemotherapy and immunotherapy. Recent trials in Holland and Germany have demonstrated that hyperthermia can prolong life and decrease disease re-appraisal when used in combination with radiotherapy and chemotherapy. Some tumors seem more responsive than others. In this brief summary we will attempt to give a vision of hyperthermia from a physical stand point, but more importantly we will give clinical and biological aspects. The results obtained in these trials on certain types of cancers such as cervix cancer, recurrent breast cancer and head neck cancer, melanoma, sarcomas, liver, glioblastoma and pancreatic cancer support the use of this technique, although some clinical and technical problems persist and have not been completely resolved.
\end{abstract}

Keywords: Heat treatment; Hyperthermia; Oncology; Heating techniques; Clinical results

\section{Introduction and Some Historical Notes}

Hyperthermia (HT) is the delivery of heat to tumor mass. However this cancer therapy has long been neglected by mainstream medicine. The principal factors that have hampered the clinical use of HT are: the reproducibility of heat deposition into the tumor mass and the not easily measurement of the temperature of the tumor mass and its surrounding tissues [1,2]. The main problem is the missing appropriate dosimetry for clinical protocols [3] Nevertheless, we can say that the application of heat or rather the rise in body temperature (fever) have begun the modern oncology [4]. Re-reading their stories, we could also say that the introduction of drugs and the abandonment of Coley's bacterial toxins coincided with a mistaken view of cancer [5]. The tumor was considered more as a foreign object that grows and which is no longer part of the organism of origin. Fortunately the nature after the many failures of high-dose chemotherapy and radiation therapy has brought us to reconsider the patient and not the tumor mass. Recognizing the complexity of the human body the combinations of the therapies and integrative approaches started to rise. The failures of radiotherapy on advanced disease, pushed Warren in 1935 to use a combination of ionizing radiation with an artificial systemic heating [6]. The data reported were interesting and 29 patients on 32 with advanced cancer experienced an immediate improvement of the general conditions and an increase in survival of 6 months All patients however experienced remission [6,7]. This interesting method of treatment (heat plus radiotherapy) was forgotten, until 1967, when Cavaliere and his group, in Rome successfully treated patients with hyperthermic limb perfusion [8] affected by metastatic melanoma and sarcoma. These researchers were the first to demonstrate some important aspects: 1st tumor cells in vitro are more sensitive than normal cells to heat; 2 nd the amount of cells killed is proportional both to the length of exposure and to the degree of temperatures to which they are exposed [7].

\section{Hyperthermia heating equipment and techniques}

Hyperthermia can be defined as a therapy able to raise the temperature in the tumor mass between 41 and $45^{\circ} \mathrm{C}$ by external physical means. The applied temperature in the complex tumor-mass cannot be kept homogeneous; the methods try to concentrate on the tumor-cells by completing the heat with complementary applications. The energy to be deposited into the tumor mass is obtained using external devices. The raising of temperatures can be loco regional or systemic heating interesting the whole body depending on the aim of the treatment.

Loco regional hyperthermia may be external, interstitial or endocavitary [9]. Single or confined tumor mass is mostly be heated by Radiofrequency (RF), microwave or ultrasound. The easiest and most effective solution was the capacitive coupling of the energy. The original device has been ameliorated peculiarly on the electrode application and on matching EM wave between the two electrodes by Siemens Germany named Thermo flux (1910) where the two electrodes were hold by the therapist. This device was renewed, (Radiotherm, 1947) [7], when the electrode holders were applied. The method was unpopular, and forgotten. One of the pioneering works trying to develop a simple and clinically applicable device was made by Harry LeVeen [10]. LeVeen et al. treated the tumor mass with a capacitive method, using the $13.56 \mathrm{MHz}$ medically free frequency in international standards [11]. The method has been applied since and is widely applied still $[12,13]$. This capacitive method (or diathermy) is based on the application of two external electrodes at opposite poles of the tumor mass. Between the two poles an Electromagnetic wave (EM) 
with a frequency of $13.56 \mathrm{MHz}$ is applied. This wave changes its polarity every 74 nanoseconds, producing standard Joule-heat by the RF-current, connected to the conductivity of the tissues, as well as "exciting" the molecules with high permittivity inside the tumor mass, producing a friction-like heating, the so-called dielectric loss, depending on the electric permittivity of the tissues. The method was further developed and commercialized by Synchrotherm Italy (1985) (Figure 1). The fact that the tumor mass has a greater volume of water and cannot dissipate the heat due to the defected microvasculature which down-regulates the blood-flow over a threshold compared to normal tissue [14], while causing vasodilatation in the healthy tissues leading to increased relative blood perfusion and heat conduction in this region $[15,16]$. This blood-flow difference allows an increase of heat in a selective way in the tumor mass [17-19].

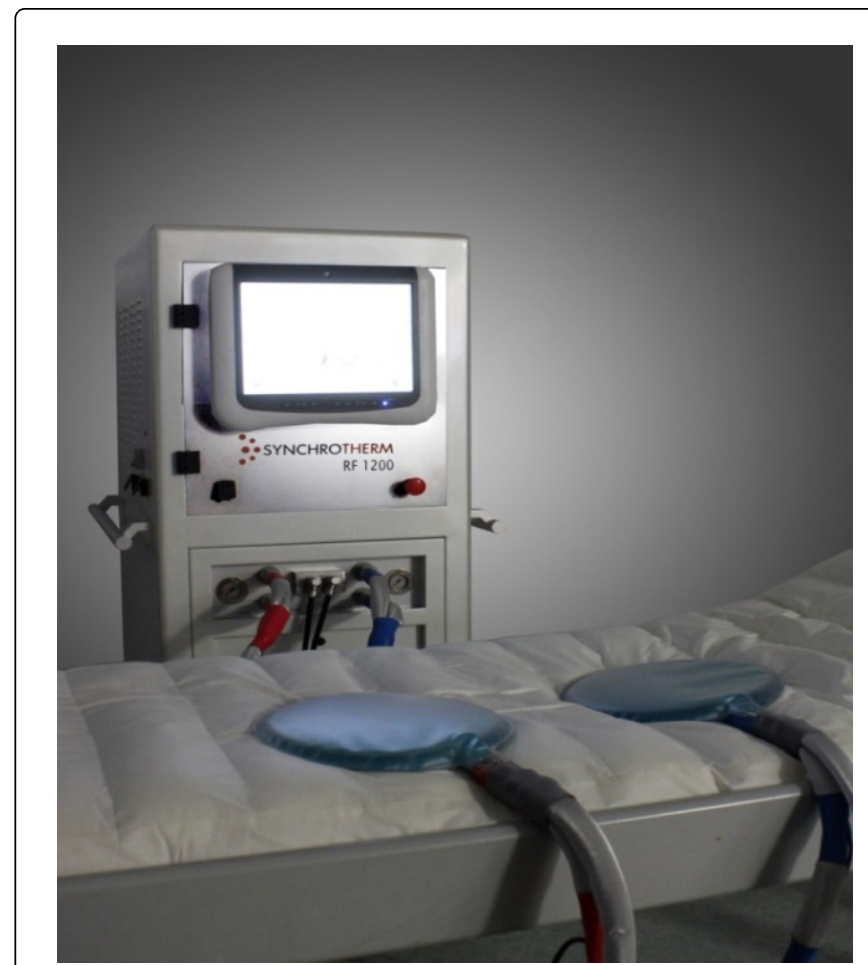

Figure 1: Synchrotherm device and electrodes are illustrated. (Reproduced with permission)

Another capacitive method similar to that of LeVeen is the Japanese Thermotron-RF8 device that works with lower frequency $(8 \mathrm{MHz})$ [20,21]. As reported by Hager and Cheung, tissue penetration by EM is function of frequency, lowering the frequency increases the penetration $[9,22]$. The two devices have a good penetration on the order of $2-15 \mathrm{~cm}$, but due to their principle of action their action is seriously limited by the fat tissue presence $[9,22]$, which could be dangerously overheated.

BSD another radiofrequency device approved by American FDA, works at frequency range between $75-120 \mathrm{MHz}$. Its peculiarity is the delivering apparatus that consists in an array of antennae surrounding the body of cancer patient and appropriately focused to concentrate the energy in three dimension (3D) at the tumor mass. For technical notes on this device see the booklet published by Daryoush Fatehi published on line.
Microwave and ultrasound applicators are two other modalities. The wave frequency for microwave is of the order of $1 \mathrm{GHz}$. As outlined by Robert et al. the heat generation results mainly from dielectric relaxation and the energy deposition are obtained by wave guided applicators [23]. For a complete review on microwave applicators see Cheung IAY, Al-Atrash J [24].

Other approach is the heating by mechanical waves. The ultrasound (US) uses frequencies between $0.5-10 \mathrm{MHz}$ and the heat production happens as the result of the absorption of this ultrasound vibration in the tissue [22]. The focused energy-deposit could be used for targeting the tumor-mass, which is applied by the recent High-Intensity Focused Ultrasound (HIFU) methodology. This methodology is also called thermal surgery due to the development of temperatures over 50 ${ }^{\circ} \mathrm{C}$ in few seconds and has been used for prostate, localized liver tumors, breast and pancreatic tumors [25-28]. Prostatic HIFU application is not without side effects, in fact as outlined by Elterman et al. urosepsis, indwelling catheterization and bladder problems occurred frequently [25]. HIFU as outlined by Zhou [27] has certain limitations, some technical are linked to the source of energy (the ultrasound), others to the length of the treatment session and to the imaging. A reliable thermometry is a limitation but this is common to many commercial devices.

Actually interstitial hyperthermia, a loco regional way of tumor treatment, is gaining a lot of consensus. Interstitial HT delivers heat to the tumor mass directly and this is accomplished using high frequency needle $(375 \mathrm{kHz})$, laser fiber optic conductors or ferromagnetic rods. Typically, this type of therapy is applied in image guided way, usually ultrasound-guided. This therapy offers many advantages compared to other invasive procedures such as reduction of morbidity and mortality. Furthermore, the technique is applied in an out- hospital way reducing the hospital costs. One kind of interstitial treatments is the definitive ablation technique [29]. The ablation methods work on a typical burn-necrosis basis, and the energy is typically provided by impedance-heating with minimally invasive electrode insertion; no heat-flow exists through the skin. Some typical applications are for liver [30], lung [31,32], breast [33]. The modern laser ablative techniques work with ultrafast pulses with ultra large energy-density flow. Depending on the pulse-duration it can be a few $100 \mathrm{~W} / \mathrm{cm}^{2}$ and in ns intervals can go to $107-108 \mathrm{~W} / \mathrm{cm}^{2}$ [34], but the provided energy altogether reaches its maximum a few tenths of watts. Their application for liver [35,36], is common. This emerging technology is more-and-more shifted to become the tool of surgery intraoperative or applied by interventional radiology, isolated a little bit from the general hyperthermia practices.

Special emerging hyperthermia in oncology is based on nanoparticle applications [37]. In this method, the nanoparticles which are usually administered in a suspension [38] are small heat-absorbers. They are selectively heated up by outside magnetic field, which acts exclusively only on these nanoparticles. The trick there is the accurate targeting of the heat-absorption. The overheated nanoparticles soon give their heat-energy to their neighborhood and heat-up the complete lesion in their vicinity. Huge energy is pumped into these nanoparticles being able to heat-up the complete mass, containing a huge amount of electrolytes. However, most of the electrolytes are uselessly heated up because the heat has to be concentrated on the tumor-cells and exclusively on their membranes to damage them decisional. This request needs a higher preciosity, addressing the nanoparticles selectively on the surface of the tumor-cells, which can be made by antibody-nanoparticle conjugates [39]. It releases of therapeutic 
targets at the connected malignant cells while minimizing off-target side effects. The nanoparticle absorption however could block the apoptotic processes induced by complementary therapies, $[40,41]$.When the delivering nanoparticle which is especially bonded to the membrane of the malignant cell is heated up by outside field, it could make double effect: damage the membrane by heat and/or release the drug which was delivered to the target [42].

A new kind of capacitive coupling was developed by oncothermia (1991, Germany). This method cuts itself adrift from the classical capacitive concepts, and instead of the plane-wave, the RF arrangement more emphasizes the impedance coupling together with multiple specialties $[43,44]$. The device is similar in its structure to capacitive hyperthermia but concentrates its heat effects on membranes of tumor cells and on the extracellular matrix in its immediate vicinity. A typical device of Oncothermia used in our institutions is illustrated (Figure 2).

It is in fact a nano-heating technology [45], (it is also called nanothermia), and in this meaning it is similar to the nanoparticle heating. The main differences from the conventional capacitive heating is summarized in Table 1.

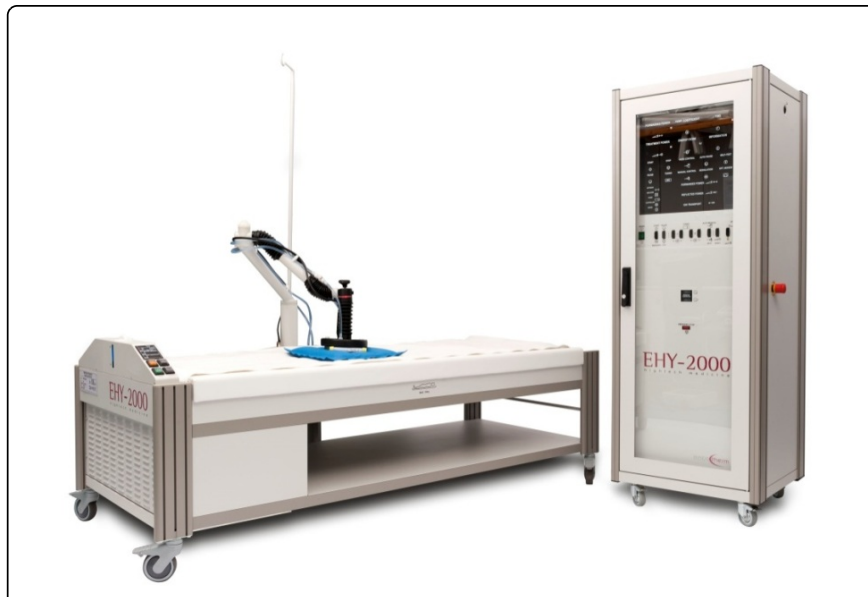

Figure 2: Oncothermia EHY 2000 device used in our institution.

\begin{tabular}{|c|c|c|c|c|}
\hline & \multicolumn{2}{|l|}{ Parameters } & Traditional Capacitive HT & Oncothermia \\
\hline \multirow[t]{4}{*}{1} & \multirow[t]{4}{*}{ Heating } & methods & $\begin{array}{l}\text { Macro-heating (selected by macroscopic } \\
\text { impedance differences) }\end{array}$ & $\begin{array}{l}\text { Microheating (nano-selected } \quad \text { by } \\
\text { microscopic impedance differences) }\end{array}$ \\
\hline & & object & Entire tumor volume & Cell membrane of malignant cells \\
\hline & & Output power & $\begin{array}{l}\text { Over } 1 \mathrm{~W} / \mathrm{cm}^{2} \text { (generally }>500 \mathrm{~W} \text { ) the goal is } \\
\text { to heat up the tumor-mass as high } \\
\text { temperature }\end{array}$ & $\begin{array}{l}\text { Less than } 0.51 \mathrm{~W} / \mathrm{cm}^{2} \text { (generally }< \\
250 \mathrm{~W} \text { ) moderate overall heating } \\
\text { high selective (nano) heating } \\
\text { enough producing }\end{array}$ \\
\hline & & focusing & $\begin{array}{l}\text { Smeared by patient movement and by heat } \\
\text { spreading by time }\end{array}$ & $\begin{array}{l}\text { Remains focused on nano-parts } \\
\text { (current follows the movements), } \\
\text { low heat-spreading due to mild } \\
\text { mass-effect }\end{array}$ \\
\hline 2 & \multicolumn{2}{|c|}{ Penetration depth (same frequency) } & Determined by the plane waves & Longer \\
\hline 3 & \multirow[t]{4}{*}{$\begin{array}{l}\text { Physiologic } \\
\text { Effect }\end{array}$} & Effect on transports & $\begin{array}{l}\text { Vasodilatation first, and vasoconstriction over } \\
\text { a threshold temperature, not controlled }\end{array}$ & $\begin{array}{l}\text { Mild overall heating, only slight } \\
\text { vasodilatation, below the } \\
\text { vasoconstriction threshold }\end{array}$ \\
\hline & & Effects on homeostatic feedbacks & $\begin{array}{l}\text { Feedback trying to reestablish the } \\
\text { homeostatic equilibrium, works against the } \\
\text { heating }\end{array}$ & $\begin{array}{l}\text { Weak homeostatic counter-actions, } \\
\text { hyperthermia acts alone }\end{array}$ \\
\hline & & Immune activation & $\begin{array}{l}\text { Immune cells are active over } 40^{\circ} \mathrm{C} \text {, it is } \\
\text { uncontrolled }\end{array}$ & $\begin{array}{l}\text { Perfect condition for immune } \\
\text { activation }\end{array}$ \\
\hline & & Surface cooling & $\begin{array}{l}\text { Strong cooling with extra bolus solution, } \\
\text { vasoconstriction in the subcutaneous tissue, } \\
\text { higher risk of electric burn by isolation layer }\end{array}$ & $\begin{array}{l}\text { Homeostatic cooling, no extra } \\
\text { (secondary)bolus cooling, keeping } \\
\text { the homeostatic equilibrium }\end{array}$ \\
\hline \multirow[t]{3}{*}{4} & \multirow[t]{3}{*}{ Adverse effects } & Support of tumor growth & $\begin{array}{l}\text { Strong vasolidation and starts to deliver more } \\
\text { glucose, competing with the cell- distortion } \\
\text { potential of heat }\end{array}$ & $\begin{array}{l}\text { Mild vasodilatation and the } \\
\text { reestablished adherent connections } \\
\text { limit the extra glucose delivery }\end{array}$ \\
\hline & & Risk of metastases & $\begin{array}{l}\text { High vasodilatation increases the risk of } \\
\text { malignant invasion and the heated healthy } \\
\text { volume risks the dissemination }\end{array}$ & $\begin{array}{l}\text { Effect of adherent connections and } \\
\text { cytoskeleton of } \begin{array}{l}\text { malignant } \\
\text { blocks the } \\
\text { dissemination } \\
\text { dissemion and }\end{array} \\
\end{array}$ \\
\hline & & Safety & Frequent burn toxicity & Rare burning toxicity \\
\hline
\end{tabular}




\begin{tabular}{|c|c|c|c|c|}
\hline \multirow[t]{3}{*}{5} & \multirow{3}{*}{$\begin{array}{l}\text { Selectivity by object and RF } \\
\text { characteristics }\end{array}$} & Tumor Conductivity & \multirow{3}{*}{$\begin{array}{l}\text { Theoretically works, but RF voltage centered } \\
\text { coupling the electrodes and the macro } \\
\text { heating cancel the effect }\end{array}$} & \multirow{3}{*}{$\begin{array}{l}\text { Effectively works with tight } \\
\text { impedance coupling by micro } \\
\text { heating loverheating cancels the } \\
\text { selectivity and the effect) }\end{array}$} \\
\hline & & Cell permittivity & & \\
\hline & & Membrane $\beta$ Dispersion & & \\
\hline 6 & Selectivity by pathologic pattern & Fractal modulation & Does not exist & Built -in \\
\hline \multirow[t]{2}{*}{7} & \multirow[t]{2}{*}{ Complementary Application } & Chemotherapy (CT) & $\begin{array}{l}\text { Forced over threshold ( }>40{ }^{\circ} \mathrm{C} \text { ) makes } \\
\text { vasoconstriction limiting drug delivery to } \\
\text { tumor }\end{array}$ & $\begin{array}{l}\text { Complete synergy with the drug } \\
\text { delivery extending the chemotaxis } \\
\text { with electrostatic }\end{array}$ \\
\hline & & Radiotherapy (RT) & $\begin{array}{l}\text { Forced over threshold }\left(>40^{\circ} \mathrm{C}\right) \text { creates } \\
\text { hypoxia decreasing the efficacy of } \mathrm{RT}\end{array}$ & $\begin{array}{l}\text { No hypoxia present -radio } \\
\text { sensitization is complete }\end{array}$ \\
\hline 8 & \multicolumn{2}{|l|}{ Heating results on cell death } & $\begin{array}{l}\text { Necrosis is dominant, minor apoptosis by } \\
\text { internal apoptotic pathways (in mitochondria) }\end{array}$ & $\begin{array}{l}\text { Dominantly apoptosis via external } \\
\text { membranes pathways (Surface cell } \\
\text { membrane) }\end{array}$ \\
\hline 9 & \multicolumn{2}{|l|}{ Electrode System } & $\begin{array}{l}\text { Symmetric electrode, Voltage dominating, } \\
\text { plane wave coupling }\end{array}$ & $\begin{array}{lcc}\text { Double } & \text { asymmetric } & \text { electrocde, } \\
\text { current } & \text { centered } & \text { impedance } \\
\text { coupling } & & \end{array}$ \\
\hline 10 & \multicolumn{2}{|l|}{ DoseFacility } & Only temperature $\left({ }^{\circ} \mathrm{C}\right)[\mathrm{CEM} 43 \mathrm{CT} \times(\mathrm{min})]$ & Energy like of ionizing radiation \\
\hline 11 & \multicolumn{2}{|l|}{ Immune activity } & $\begin{array}{l}\text { Uncontrolled immune effects, necrosis [CEM } \\
43 \mathrm{CT} \times(\mathrm{min})]\end{array}$ & $\begin{array}{l}\text { Massive production of apoptotic } \\
\text { bodies with production of Danger } \\
\text { Signals }\end{array}$ \\
\hline 12 & \multicolumn{2}{|l|}{ Abscopal effect } & Rare abscopal conditions & $\begin{array}{l}\text { Abscopal conditions, immunogenic } \\
\text { cell death }\end{array}$ \\
\hline
\end{tabular}

Table 1: Comparison of Classical Capacitive HT with Oncothermia on various physical, physiological and biologic parameters

Oncothermia solves this problem without artificial nano-particle delivery. Oncothermia selectively targets the membrane rafts of the malignant cells ( $5 \mathrm{~nm}$ range) and delivers energy for their heating up clearly performing the classical hyperthermia process in nano-range [45]. Oncothermia is a capacitive impedance coupled energyabsorption, it heats the sensitive parts of the malignant cells selectively and effectively. The details of these effects were discussed in numerous papers and chapters of books [43,46-53].

Oncothermia is hyperthermia, only it heats up not the complete tumor mass, but the membranes rafts selectively. It determines a wellabsorbed energy on the targeted volume, initializing special effects by their extreme thermal potential, orienting the massive cellular distortion in malignant cells [54]. This method is devoted to keep all positive effects of conventional hyperthermia together with improvement of the imperfections and answer on the challenges. The clue is the microscopic (nanorange) energy-liberation instead of the overall heating of the mass of target [55]. Their selection is based on the high glucose metabolism of the malignant cells (Warburg effect [56], special electromagnetic environment of the malignant cells (Szentgyorgyi effect) [57], with Schwan's beta/delta-dispersion [58-60], and the pattern of malignancy [61-64] which deviates from their healthy neighborhood, and breaks the "social" signals which are commonly regulating and controlling the healthy cells [65]. Detailed explanation of oncothermia as method was made elsewhere $[42,66]$, and its technical realization was published too [67].

Oncothermia is a highly sophisticated method trying to answer on some of the challenges of hyperthermia [68], and is intended to reintroduce hyperthermia by new standards [69]. It is based on a strong synergy between the temperature and the electric field [70]. The Radiofrequency (RF) current is chosen with a proper amplitude modulated radiofrequency [71], which is absorbed by the nanoscopic range of the malignant cells (45). The physiological differences of the malignant cells from their healthy counterparts [68] distinguishes the malignancy which is self-selected by additional time-fractal modulation [72], and on such way it is also highly personalized [73].

\section{Biological effects of hyperthermia}

The biological response of the tumor to heat depends on both the intrinsic characteristics of the tumor cell itself and on the surrounding environment. Indeed modifications of the tumor microenvironment may increase or decrease the response to heat [74].

Between the range of 40 and $43^{\circ} \mathrm{C}$, the majority of cancer cells tend to die, while the majority of healthy cells tend to survive [75]. When cancer cells are subjected to high temperatures $\left(40-43^{\circ} \mathrm{C}\right)$ they suffer irreversible damage, in a time and dose dependent way. Heat cell killing occurs exponentially as function of time and dose and its shape is not dissimilar from those obtained by X-rays [76]

The biochemical processes affected by heat are several, as outlined by Pietrangeli and Mondovi [75], and are here summarized:

- DNA, RNA synthesis, DNA repair mechanism and cell respiration are inhibited

- Tumor cell membranes in presence of heat become more permeable and fluid. This may partially explain the increased uptake of drugs.

- DNA polymerases- $\beta$ key enzymes in multistep repair system and are strongly inhibited.

- Mitochondria suffer different alterations in their cristae 
- Enhanced production of heat shock proteins (hsp) is common and this affects thermo-tolerance and tumor immunogenicity.

- Heat increases the influx of reactive oxygen radicals mediating in part the cytotoxicity

- Hyperthermia in combination with drugs promoting apoptosis, has synergistic effect [76]

The greater sensitivity of tumor cells to heat depends from these biochemical effects but also by the microenvironment in which the tumor cells are embedded [73,74].

Tumor cannot grows over a mass $>$ of $1-2 \mathrm{~mm}^{3}\left(10^{6}\right.$ cells $)$ without organizing a nutritive support through a new vasculature. The neovasculature is however insufficient and in the majority of case is disorganized and lacking an ordered hierarchy. The net result even if there is a new vascularization is an imperfect oxygenation and a presence of areas of hypoxia and necrosis. These areas are not distributed evenly in the tumor mass. The result at the cellular level is a combination of low $\mathrm{pH}$, low presence of oxygen, shortage of sugars and other nutrients. The cancer cell that grows at a distance from the capillaries $>$ of $100-200 \mu \mathrm{m}$ is unable to obtain sufficient oxygen and nutrients and becomes a suffering cell. These suffering cells to ameliorate their state trigger a defense system called Hypoxia Inducible Factor (HIF). HIF is sensitive to oxygen and to resolve this undernourished and hypoxic state induce the production of Vascular Endothelial Factor (VEGF) by tumor cells and its stroma. The principal action of VEGF is the production of neo angiogenesis but triggers also inflammatory reaction. HIF, furthermore, determines the metabolic conversion in tumours to anaerobic glycolysis, the so-called Warburg effect. Following Warburg effect a lot of lactic acid is produced and the extracellular $\mathrm{pH}$ becomes acidic producing many biological effects that are out of this discussion [56,76,77]. The acidic and hypoxic environment has negative effects on chemotherapy and radiotherapy, but seems to benefit hyperthermia (Table 2). This hostile environment does not interfere on the action of hyperthermia as demonstrated in glioblastomas by Koutcher and Gerweck [79,80], indeed it seems that hyperthermia could benefit especially for the cells in a state of acute hypoxia compared to those subjected to chronic hypoxia [78-80]. Hahn et al. have shown that metabolic state and energy deprivation increase the heat sensitivity [81]. This aspect, suggests the use of HT with Trans Arterial Chemoembolization (TACE) Another important aspect is related to the change in the composition of the membranes as shown by the groups of Tanaka $\mathrm{H}$ and Kokura suggested by one of our group already in 1995 [82-84].

\begin{tabular}{|l|l|l|l|l|}
\hline $\begin{array}{l}\text { Tumor Structure } \\
\text { Cells Affected }\end{array}$ & Chemotherapy & $\begin{array}{l}\text { Radiotherap } \\
\text { y }\end{array}$ & HT & Immunotherapy \\
\hline Oxygenated Cells & ++ & ++ & +++ & +++ \\
\hline Hypoxic Cells & +- & -- & +++ & ++ \\
\hline Vascular Structure & + & ++ & +++ & +- \\
\hline Stroma & + & + & ++ & ++ \\
\hline Microcirculation & - & + & ++ & + \\
\hline
\end{tabular}

Table 2: Comparison of the effects of HT, Radiotherapy, Chemotherapy and immunotherapy on several cells and tumor structure
Before discussing the positive association between radiotherapy chemotherapy and hyperthermia is useful to discuss the effects of hyperthermia on tumor apoptosis. As reported by Wong [85] apoptosis is an ordered, balanced and programmed cell death process normally present in all cells but lacking in tumor. The tumor tends to have a reduced apoptosis due to a disrupted balance of pro-apoptotic and anti-apoptotic proteins such as Bcl-2 family proteins, p53 expression, and reduced caspase activity, abnormalities of death receptor signaling, or increased endogenous Inhibitors of Apoptosis Proteins (IAPs) [85].Hyperthermia as evidenced by Ahmed and Zaidi enhances apoptosis [86]. HT leads to increased apoptosis through several biologic processes as increased tumor membranes permeability, increased production of oxygen free radicals, inhibition of DNA repair and alteration of cellular cytoskeleton [86,87]. Other authors have demonstrated that the enhanced apoptotic effect of hyperthermia happens by changing the expression of apoptosis genes, such as p53, Bcl-2 and Bax [88]. Other authors have experimentally shown, at least in melanoma, that the apoptotic effect of HT is obtained by activating not caspases 8 or 9 but activating a nonconventional apoptotic pathway caspases 3/7 [89].

Another important biologic effect of HT is the capacity to enhance the antigenic presentation to effector cells, and the production of heat shock proteins (hsp) [90-93]. Furthermore, HT recruits into the tumor area neutrophils, macrophages, natural killer cells, myeloid suppressor cells and regulatory $\mathrm{T}$ cells [92-94]. The recruitment of these cells into the tumor area is normally induced by the hypoxia and coincides with a state of immune suppression [93,95-98]. Hyperthermia as outlined by Repasky group has the ability to increase the perfusion and the oxygenation (see paragraph hyperthermia radiotherapy) of the tumor area reducing so the immune suppressive state and increasing the effectiveness of immunotherapy [93,96]. The association of radiotherapy and hyperthermia, does not only increase the action of radiotherapy but as outlined by Muthana et al. can also affect the behavior of the regulatory $\mathrm{T}$ cells and the macrophage activity [94]. In fact, the association of the two therapies decrease the recruitment of the regulatory $\mathrm{T}$ cells, compared to hyperthermia alone, and macrophages seems to be affected by this association, decreasing the expression of M2 types [94]. Furthermore, reprogramming in the tumour microenvironment macrophages, hyperthermia in vivo modulates many aspects of innate and adaptive immunity, such as Natural Killers or heat shock proteins $[94,97,98]$ aiding in tumour eradication hallmark of cancer, with its auto sustaining abilities regarding inflammation [90]. The increase of induced by hyperthermia [97], particularly HSP 70, has been found to act as a recognition structure for Natural Killer (NK) cells, increasing their activity [97-100].

Another important anti-tumor effect of HT is the capacity to inhibit angiogenesis. In the late 1988 Fajardo et al. demonstrated that capillary endothelial cells were thermo sensitive. The extent of inhibition was inversely proportional to temperature [101]. Recently Roca et al. have shown that Hyperthermia inhibit angiogenesis in vitro and in vivo by controlling extracellular matrix degradation through the induction of Plasminogen activator inhibitor-1 (PAI-1) [102].

Previous information shows that hyperthermia thanks to its various biological and physiological effects can be used positively with radiation therapy and chemotherapy. A recent review by Horsman has clearly demonstrated that hyperthermia is a potent enhancer of radiotherapy [103]. This effect is evident in vitro and in vivo and from clinical trials emerge that the association improves both local control 
and survival, without increasing the side effects [103]. According to Horsman [103] and Schildkopf [104] the reasons for the radio sensitization are several and involve tumor vasculature and oxygenation, inhibition of DNA repair mechanism and the increased formation of toxic DNA double strand breaks. Song et al. since 1985 outlined the importance of hyperthermia in improving perfusion and oxygenation $[14,16,17]$. These authors noted that this effect was present at mild hyperthermia $\left(40-42^{\circ} \mathrm{C}\right)$ and that an enhanced response to radiotherapy and chemotherapy was present [105]. Despite the increased response by combining radiation and hyperthermia as demonstrated by several clinical trials (see the following paragraph), several authors haves sown that the improvement in perfusion and oxygenation is not unique and shows a great variability $[106,107]$. This variability is related in part to the heterogeneity in the organization of tumor neo vasculature and in part to non-uniform distribution of regional regulatory mechanisms inside it $[106,108]$.

Chemotherapy is regarded as the only rational approach to cancer therapy, but it is full of side effects and a number of failures [109]. For chemotherapy we do not just mean the use of cytostatic drugs but also the use of monoclonal antibodies. The reduction of the side effects of chemotherapy and an increase in its effectiveness is certainly a desired result. Preliminary studies of Engelhardt [110], Dahl [111], Hahn [112] Urano [113] and Issels [114] have revealed that hyperthermia showed a synergism with chemotherapy as well as with radiotherapy. We have summarized the synergism and activity of drugs and HT in various micro-environmental conditions, in Table 3. Nevertheless oncologists have shown a deep distrust and ignorance about the use of this association.

\begin{tabular}{|l|l|l|l|l|}
\hline Chemotherapy & $\mathbf{H T}$ & $\begin{array}{l}\text { Oxygenated } \\
\text { Cells }\end{array}$ & Hypoxic Cells & $\mathbf{p H} \leq 7$ \\
\hline Adriamicin & $\uparrow \uparrow$ & $\uparrow \uparrow$ & ND & ND \\
\hline Cyclophosphamide & $\uparrow \uparrow$ & $\uparrow \uparrow$ & ND & ND \\
\hline Bleomycin & $\uparrow \uparrow \uparrow$ & $\uparrow \uparrow$ & $\uparrow \uparrow \uparrow$ & $\uparrow \uparrow \uparrow$ \\
\hline Mitomycin-C & $\uparrow \uparrow$ & $\uparrow \uparrow \uparrow$ & $\uparrow \uparrow \uparrow$ & $\uparrow \uparrow \uparrow$ \\
\hline BCNU/TMZ & $\uparrow \uparrow$ & $\uparrow$ & $\uparrow \uparrow$ & $\uparrow \uparrow$ \\
\hline Carboplatin & $\uparrow \uparrow$ & $\uparrow$ & $\uparrow \uparrow \uparrow$ & $\uparrow$ \\
\hline Vincristine & $\uparrow$ & $\uparrow$ & ND & ND \\
\hline Methotrexate & $\uparrow$ & $\uparrow$ & ND & ND \\
\hline 5FU & $\uparrow$ & $\uparrow$ & ND & ND \\
\hline $\begin{array}{l}\text { ND: not determined; } \uparrow: \text { association strength, BCNU/TMZ: Carmustine } \\
\text { (bischloroethylnitrosourea)/ Temozolomide }\end{array}$ & \\
\hline
\end{tabular}

Table 3: Possible association of chemotherapy with HT and possible potentiation of drugs by $\mathrm{HT}$ on oxygenated, hypoxic and $\mathrm{pH}$

The activity of drugs in presence of hyperthermia is in the majority of cases additive and increase with the increase of the temperature $[112,115]$. A right combination, as illustrated in Table 3, can treat all the cell populations present in the tumor environment (oxygenated, hypoxic, cells in acidic microenvironment). When we use drugs and HT, the drugs behavior can be according to Hahn [112] and Dietzel [115] of three types. The first recognized type is drugs increase their activity slightly with temperature. Example of these kind of drugs are,
Thio-TEPA, Carmustine, lomustine and methyl-CCNU. The second type of behavior, is drugs exhibit increased effectiveness above $42^{\circ} \mathrm{C}$. Example of this kind of drugs is Bleomycin. The third type of response regards drugs not active at physiological temperatures but becoming active at temperature of $42^{\circ} \mathrm{C}$, see Amphotericin B [115].

Another important aspect to take into consideration is the sequence of administration of heat drugs and Radiotherapy. Regarding the association hyperthermia and radiotherapy Overgaard [116] has clearly demonstrated that the maximum effect is obtained when the two treatment modalities are used synchronously, but as observed by the author this is clinically impractical and therefore should be used in sequence. The clinical data show that the synergism between hyperthermia and radiotherapy can be observed applying HT before or after RT for a period of 4-8 hours. Other authors consider that the additive effect practically disappears if the two therapies are performed at a distance of more than two hours before or after [117].

Chemotherapy may be used synchronously, and generally as noted in the previous section, its activity is additive. The only drug that should be used with caution with hyperthermia and usually after 24 hours is the gemcitabine [117]. The possible interaction of drugs with hyperthermia and with the various physiological parameters present in the tumor microenvironment is illustrated in Table 3. As it is possible to see the synergism between HT and drugs is more useful for hypoxic cells. Another important synergism is between Radiotherapy, chemotherapy and HT (trimodality therapy). In this case the result in the local control of the tumor depends from the sequence of the treatment as demonstrated by Teicher et al for bleomycin, HT and radiotherapy [118]. The authors have demonstrated that Bleomycin is more toxic towards hypoxic cells in presence of HT and that the most successful sequence for obtaining a greater killing effect is bleomycin followed by HT and then by radiotherapy [119]. A right sequence does not have only a better local control of tumor and a decrease in side effects but may control the immune response too. In fact as described by Lee [93] and Muthana [94] and summarized in Table 4, a right sequence between chemotherapy, radiotherapy and HT could control many suppressive cells (Myeloid derived suppressor cells, Regulatory $\mathrm{T}$ cells) reducing the suppressive arm of immunity. In the future, studies covering the interaction between chemotherapy, radiotherapy and drugs able to modulate myeloid cells or regulatory $\mathrm{T}$ cells (i.e. programmed death-1 [PD-1] and T lymphocyte antigen-4 [CTLA] inhibitors) are desirable $[95,120]$.

\begin{tabular}{|l|l|l|l|}
\hline Chemotherapy & MDSCs & Tregs & HT \\
\hline Gemcitabine & Direct toxicity & & $\uparrow$ \\
\hline TRA & Elimination of transformation & & NA \\
\hline 5FU & Cell death & reduction & $\uparrow$ \\
\hline $\begin{array}{l}\text { Cyclophosphasmid } \\
\text { e }\end{array}$ & reduction & $\uparrow \uparrow$ \\
\hline Sunitib & reduction & & NA \\
\hline COX2 Inhibitors & reduction & reduction & $\uparrow$ \\
\hline $\begin{array}{l}\text { MDSCs: Myeloid derived suppressor cells; Tregs: T regulatory cells; TRA: trans } \\
\text { retinoic acid; Na: not acquired; } \uparrow: \text { increase }\end{array}$ \\
\hline
\end{tabular}

Table 4: Possible effects of chemotherapy/radiotherapy + HT on Myeloid derived cells and on T regulatory cells (Tregs) 
Page 7 of 10

\section{Clinical Benefits of Hyperthermia}

In medicine, the results from clinical trials with appropriate statistical means, give us safety in the therapeutic methods useful for treating a specific disease. Several studies have been performed with the appropriate statistical means on hyperthermia and are summarized in Table 5 for RF and MW methods and in Table 6 for oncothermia. The data are not exhaustive and are a collection of those published by several authors [9,121-123]. Analyzing these results it is evident that hyperthermia is really additive methods of treatment, alone is less efficacious and even some success has been obtained, this remains a simple isolated case or a lucky case.

\begin{tabular}{|l|l|l|l|l|}
\hline & Tumor Histology & Number of patients & CR\% & OR \% \\
\hline RT & Melanoma [124] & 19 & 21 & 32 \\
\hline RT & Head \& Neck [125] & 106 & 34 & \\
\hline RT & $\begin{array}{l}\text { Breast Advanced primary } \\
- \text { recurrent [126] }\end{array}$ & 307 & 59 & \\
\hline RT & Cervical cancer [127] & 114 & 83 & \\
\hline RT & Rectal cancer [127] & 143 & 21 & \\
\hline RT & Bladder Cancer [127] & 101 & 73 & \\
\hline RT & Glioblastoma [128] & 79 & 31 & \\
\hline CT & $\begin{array}{l}\text { Oesophageal carcinoma } \\
{[129]}\end{array}$ & 40 & & 41 \\
\hline * & Rectum [130] & 36 & & $\uparrow$ \\
\hline * & Liver [131] & 80 & & $\uparrow$ \\
\hline * & Gastric Cancer [132] & 33 & $39 \uparrow$ \\
\hline $\begin{array}{l}\text { CR\%: complete response compared to RT or chemotherapy (CT) alone; OR: } \\
\text { overall response; } \uparrow \text { increase in survival; * Trimodality therapy }\end{array}$ \\
\hline
\end{tabular}

Table 5: Results of Hyperthermia used with Radiotherapy (RT) and chemotherapy $(C)$ and with trimodality therapy * (modified by 9,122 , 123)

\begin{tabular}{|l|l|l|}
\hline Tumor Histology & Number of patients & $\begin{array}{l}\text { Median of Survival } \\
\text { (months) }\end{array}$ \\
\hline $\begin{array}{l}\text { Advanced, relapsed brain } \\
\text { gliomas, Phase II, retrospective } \\
\text { [133] }\end{array}$ & 12 & 10 \\
\hline Glioblastoma [134] & 92 & 16 \\
\hline Gastric Cancer [135] & RT 16 & 81 \\
\hline “ & “ & “ \\
\hline “ & * 4 & 25 \\
\hline $\begin{array}{l}\text { Liver metastases colon rectal } \\
\text { origin [136] }\end{array}$ & 22 & 28 \\
\hline $\begin{array}{l}\text { Colon Cancer Phase } \\
\text { prospective [137] }\end{array}$ & 154 & 75 \\
\hline & CTM 53 & 81 \\
\hline & Only Oncothermia 50 & \\
\hline
\end{tabular}

\begin{tabular}{|l|l|l|}
\hline & CT 51 & 91 \\
\hline Ref: references; CTM: Chinese traditional medicine, CT: chemotherapy \\
\hline
\end{tabular}

Table 6: Summary of the studies made by oncothermia treatment

\section{Conclusions}

Using the words of Dewhirst [138] (who reported Eric Hall) we can say that "the biology is with us, but the physics is against us". The situation has not changed since 1994, and hyperthermia at least in the United States followed by the majority of countries has abandoned this treatment technique. Only Germany and the Netherlands have continued to study this methodology. The reasons for this neglect are many and as expressed by Dewhirst very much related to the fact that until a few decades ago there were no effective means to store energy in the tissues and ability to clinically determine the temperature reached. Currently some companies are developing other methods to overcome these obstacles. What is sure is that the response to the heat of the tumor is in favor of the patient. This resulted in at least some countries to use the technique privately and out of hospitals, losing in some cases seriousness. Only the method of interstitial hyperthermia techniques has had a strong development, but we have not described simply because we are not skilled in this application.

\section{References}

1. Field SB, Hand JW (1990) Introduction. In: An Introduction to the practical Aspects of Clinical Hyperthermia. Taylor \& Francis (Edr.), London, New York, Philadelphia.

2. WK Hong, RC Bast, W N Hait, DW Kufe, RE Pollock, et al. (2010) Hyperthermia. In: Cancer Medicine. (8th Edn.), USA.

3. Jones E, Thrall D, Dewhirst MW, Vujaskovic Z (2006) Prospective thermal dosimetry: the key to hyperthermia's future. Int J Hyperthermia 22: $247-253$.

4. Bull JM (1983) Systemic Hyperthermia: background and principles. In: Hyperthermia in Cancer Therapy, G.K. Hall Medical Publishers, Boston.

5. Wiemann B, Starnes CO (1994) Coley's toxins, tumor necrosis factor and cancer research: a historical perspective. PharmacolTher 64: 529-564.

6. Warren SL (1935) Preliminary study of the effect of artificial fever upon hopeless tumor cases. AM J Roentgenol Radium Ther 33: 75-87.

7. Seegenschmiedt MH, Vernon CC (1995) A historical perspective on hyperthermia in Oncology. In: Thermoradiotherapy and thermochemotherapy. MH Seegenschmiedt, P Fessenden, CC Vernon (Eds.), Springer Berlin Heidelberg, New York.

8. Cavaliere R, Ciocatto EC, Giovanella BC, Heidelberger C, Johnson RO, et al. (1967) Selective heat sensitivity of cancer cells. Biochemical and clinical studies. Cancer 20: 1351-1381.

9. Gianfranco Baronzio, Hager ED (2006) Locoregional Hyperthermia. In: Hyperthermia in Cancer Tratment: a primer. Landes and Springer Science, New York, USA.

10. LeVeen HH, Wapnick S, Piccone V, Falk G, Ahmed Nafis (1976) Tumor eradication by radiofrequency therapy. Responses in 21 patients. JAMA 235: 2198-2200.

11. LeVeen HH, Ahmed N, Piccone VA, Shugaar S, Falk G (1980) Radiofrequency therapy: clinical experience. Ann N Y AcadSci 335: 362-371.

12. Short JG, Turner PF (1980) Physical Hyperthermia and Cancer Therapy. Proceedings of the IEEE 68: 133-142.

13. Storm FK, Morton DL, Kaiser LR, Harrison WH, Elliott RS, et al. (1982) Clinical radiofrequency hyperthermia: a review. Natl Cancer InstMonogr 61: 343-350. 
14. Song CW, Lokshina A, Rhee JG, Patten M, Levitt SH (1984) Implication of blood flow in hyperthermic treatment of tumors. IEEE Trans Biomed Eng 31: 9-16.

15. Song CW, Choi IB, Nah BS, Sahu SK, Osborn JL, et al. (1995) Microvasculature and Persfusion in Normal Tissues and Tumors. Seegenschmiedt MH, Fessenden P, Vernon CC (Eds.), USA.

16. Song CW, Park H, Griffin RJ (2001) Theoretical and Experimental Basis of Hyperthermia. In: Thermotherapy for Neoplasia, Inflammation, and Pain. Springer Japan, Tokyo.

17. Song CW (1984) Effect of local hyperthermia on blood flow and microenvironment: a review. Cancer Res 44: 4721s-4730s.

18. Hahn GM (2012) Blood-flow. In: Physics and Technology of hyperthermia. Field SB, Franconi C (Eds.), Springer Netherlands, Boston.

19. Song CW, Choi IB, Nah BS, et al. (1996) Microvasculature and perfusion in Normal tissues and tumors. In: Thermo-radiotherapy and Thermochemotherapy. Seegenschmiedt MH, Fessenden P, Vernon CC (Eds.), Springer, Berlin Heidelberg.

20. Abe M, Hiraoka M, Takahashi M, Egawa S, Matsuda C, et al. (1986) Multi-institutional studies on hyperthermia using an $8-\mathrm{MHz}$ radiofrequency capacitive heating device (Thermotron RF-8) in combination with radiation for cancer therapy. Cancer 58: 1589-1595.

21. Imamura M, Seki T, Kunieda K, Nakatani S, Tamai T, et al. (1996) Potential applicability of clinical hyperthermia using a Thermotron-RF8 as assessed from thermal distribution in an agar phantom containing hydroxyapatite. Oncol Rep 3(6): 1017-1019.

22. Cheung AY, Neyzari A (1984) Deep local hyperthermia for cancer therapy: external electromagnetic and ultrasound techniques. Cancer Res 44: 4736s-4744s.

23. Robert J, Escanye JM, Brunotte F, Itty C (1986) Physical basis of Hyperthermia. In: Hyperthermia In Cancer Treatment, Leopold Anghileri and Jacques Robert (Eds.), CRC press.

24. Cheung IAY, Al-Atrash J (1987) Microwave hyperthermia for cancer therapy IEE Proceedings.

25. Elterman DS, Barkin J, Radomski SB, Fleshner NE, Liu B, et al. (2011) Results of high intensity focused ultrasound treatment of prostate cancer: early Canadian experience at a single center. Can J Urol 18: 6037-6042.

26. Malietzis G, Monzon L, Hand J, Wasan H, Leen E, et al. (2013) Highintensity focused ultrasound: advances in technology and experimental trials support enhanced utility of focused ultrasound surgery in oncology. Br J Radiol 1024: 20130044.

27. Zhou YF (2011) High intensity focused ultrasound in clinical tumor ablation. World J ClinOncol 2: 8-27.

28. Xiaoping L, Leizhen Z (2013) Advances of high intensity focused ultrasound (HIFU) for pancreatic cancer. Int J Hyperthermia 29: 678-682.

29. Ellis LM, Curley SA, Tanabe KK (2003) Radiofrequency ablation of cancer. Springer Verlag, New York, Berlin.

30. Goldberg SN, Gazelle GS, Solbiati L, Livraghi T, Tanabe KK, et al. (1998) Ablation of liver tumors using percutaneous RF therapy. AJR Am J Roentgenol 170: 1023-1028.

31. Okuma T, Matsuoka T, Yamamoto A, Oyama Y, Inoue K, et al. (2007) Factors contributing to cavitation after CT-guided percutaneous radiofrequency ablation for lung tumors. J VascIntervRadiol 18: 399-404.

32. Chhajed PN, Tamm M (2003) Radiofrequency heat ablation for lung tumors: potential applications. Med SciMonit 9: ED5-7.

33. Vargas HI, Dooley WC, Gardner RA, Gonzalez KD, Venegas R, et al. (2004) Focused microwave phased array thermotherapy for ablation of early-stage breast cancer: results of thermal dose escalation. Ann SurgOncol 11: 139-146.

34. Ara G, Anderson RR, Mandel KG, Ottesen M, Oseroff AR (1990) Irradiation of pigmented melanoma cells with high intensity pulsed radiation generates acoustic waves and kills cells. Lasers Surg Med 10: 52-59.

35. Walser EM (2005) Percutaneous laser ablation in the treatment of hepatocellular carcinoma with a tumor size of $4 \mathrm{~cm}$ or smaller: analysis of factors affecting the achievement of tumor necrosis. J VascIntervRadiol 16: 1427-1429.

36. Pacella CM, Valle D, Bizzarri G, Pacella S, Brunetti M, et al. (2006) Percutaneous laser ablation in patients with isolated unresectable liver metastases from colorectal cancer: Results of a phase II study. ActaOncol 45: 77-83.

37. Brannon-Peppas L, Blanchette JO (2004) Nanoparticle and targeted systems for cancer therapy. Adv Drug Deliv Rev 56: 1649-1659.

38. Jordan A, Scholz R, Wust P, Faehling H, Felix R (1999) Magnetic fluid hyperthermia $(\mathrm{MFH})$ : Caner treatment with AC magnetic field induced excitation of biocompatible supermegnetic nanoparticles. J MagnMagn Mater 201: 413-419.

39. Secret E, Smith K, Dubljevic V, Moore E, Macardle P, et al. (2013) Antibody-functionalized porous silicon nanoparticles for vectorization of hydrophobic drugs. AdvHealthc Mater 2: 718-727.

40. Yoshihisa Y, Zhao QL, Hassan MA, Wei ZL, Furuichi M, et al. (2011) $\mathrm{SOD} /$ catalase mimetic platinum nanoparticles inhibit heat-induced apoptosis in human lymphoma U937 and HH cells. Free Radic Res 45: 326-335.

41. Jawaid P, Rehman MU, Yoshihisa Y, Li P, Zhao QL, et al. (2014) Effects of SOD/catalase mimetic platinum nanoparticles on radiation-induced apoptosis in human lymphoma U937 cells. Apoptosis 19: 1006-1016.

42. Sperling RA, Rivera Gil P, Zhang F, Zanella M, Parak WJ (2008) Biological applications of gold nanoparticles. ChemSoc Rev 37: 1896-1908.

43. Szasz A, Szasz N, Szasz O (2010) Oncothermia: Principles and Practices. Springer.

44. Szasz A, Morita T (2012) Heat therapy in oncology-Oncothermia. In: New paradigm in Hyperthermia, Nippon Gyorosha, Tokyo.

45. Szasz A (2013) Electromagnetic effects of nanoscale range. In: Cellular response to physical stress and therapeutic application, Shimizu T, Kondo T (Eds.), Nova Science Publishers.

46. Szasz A, Szasz N, Szasz O (2013) Local hyperthermia in oncology. In: Hyperthermia.

47. Szasz A (2003) Physical background and technical realization of hyperthermia. In: Locoregional Radiofrequency-Perfusional- and Wholebody- Hyperthermia in Cancer Treatment: New clinical aspects. Baronzio GF, Gramaglia A (Eds.), Landes Bioscience.

48. Szasz O (2013) Essentials of oncothermia. Conference Papers in Medicine.

49. Szasz O (2013) Burden of Oncothermia: Why is it special?. Conference Papers in Medicine.

50. Szasz O, Szasz N, Meggyeshazi N (2013) Oncothermia as personalized treatment option. Conference Papers in Medicin.

51. Szasz O, Andocs G, Meggyeshazi N (2013) Modulation effect in oncothermia. Conference Papers in Medicine.

52. Meggyeshazi N, Andocs G, Krenacs T (2013) Programmed cell death induced by modulated electrohyperthermia. Conference Papers in Medicine.

53. Jeung TS, Ma SY, Yu S, Lim S (2013) Cases that respond to oncothermia monotherapy. Conference Papers in Medicine, 2013.

54. Andocs G, Renner H, Balogh L, Fonyad L, Jakab C, et al. (2009) Strong synergy of heat and modulated electromagnetic field in tumor cell killing. StrahlentherOnkol 185: 120-126.

55. Andocs G, Szasz O, Szasz A (2009) Oncothermia treatment of cancer: from the laboratory to clinic. ElectromagnBiol Med 28: 148-165.

56. Warburg O (1969) Oxygen, The Creator of Differentiation, Biochemical Energetics, Academic Press, New York.

57. Szentgyorgyi A (1968) Bioelectronics, A Study on Cellular Regulations, Defense and Cancer. Academic Press, New York, London.

58. Pething R (1979) Dielectric and Electronic Properties of Biological Materials. Wiley, New Jersey.

59. Schwan HP (1968) Determination of biological impedances. In: Physical Techniques in Biological Research. Academic Press, New York. 
60. Loft SM (1992) Bioimpedance and cancer therapy. In: The 8th International Conference on Electrical Bio-impedance, Lahtinen T (Eds.), University of Kuopio, Finnland.

61. Goldberger AL, Amaral LA, Hausdorff JM, IvanovPCh, Peng CK, et al. (2002) Fractal dynamics in physiology: alterations with disease and aging. ProcNatlAcadSci U S A 99 Suppl 1: 2466-2472.

62. Baish JW, Jain RK (2000) Fractals and Cancers. Cancer Res 60: 3683-3688.

63. Delides A, Panayiotides I, Alegakis A, Kyroudi A, Banis C, et al. (2005) Fractal dimension as a prognostic factor for laryngeal carcinoma. Anticancer Res 25: 2141-2144.

64. Tambasco M, Magliocco AM (2008) Relationship between tumor grade and computed architectural complexity in breast cancer specimens. Hum Pathol 39: 740-746.

65. Raff MC (1992) Social controls on cell survival and cell death. Nature 356: $397-400$.

66. Szasz O (2013) Burden of Oncothermia: Why is it special?, Conference Papers in Medicine.

67. Szasz A (2003) Physical background and technical realization of hyperthermia. In: Locoregional Radiofrequency-Perfusional- And Wholebody Hyperthermia in Cancer Treatment: New clinical aspects. Baronzio GF, Hager ED (Eds.), Springer Science Eurekah.com.

68. Szasz A (2013) Challenges and solutions in oncological hyperthermia. Thermal Med 29: 1-23.

69. Szasz A, Szasz N, Szasz O (2013) Local hyperthermia in oncology. In: Hyperthermia. Huilgol N (Eds.), InTech.

70. Andocs G, Renner H, Balogh L, Fonyad L, Jakab C, et al. (2009) Strong synergy of heat and modulated electromagnetic field in tumor cell killing. StrahlentherOnkol 185: 120-126.

71. Szasz O (2013) Essentials of oncothermia. Conference Papers in Medicine.

72. Szasz O, Andocs G, Meggyeshazi N (2013) Modulation effect in oncothermia. Conference Papers in Medicine.

73. Szasz O, Szasz N, Meggyeshazi N (2013) Oncothermia as personalized treatment option. Conference Papers in Medicine.

74. Pontiggia P, McLaren JR, Baronzio GF, Freitas I (1990) The biological responses to heat. AdvExp Med Biol 267: 271-291.

75. Pietrangeli $\mathrm{P}$ and Mondovì $\mathrm{B}$ (2006) On the biochemical basis of tumor damage by Hyperthermia. In: Hyperthermia in Cancer Tratment: a primer. Gianfranco Baronzio and E Dieter Hager (Eds.), LandesBioScience.

76. Cui ZG, Piao JL, Rehman MU, Ogawa R, Li P, et al. (2014) Molecular mechanisms of hyperthermia-induced apoptosis enhanced by withaferin A. Eur J Pharmacol 723: 99-107.

77. Baronzio GF, Gramaglia A, Baronzio A, Freitas I (2006) Influence of tumor microenvironment on Thermo response: Biological and clinical implications. In: Hyperthermia in Cancer Treatment: a primer. Gianfranco Baronzio and E Dieter Hager (Eds.), Landes and Springer Science+ Business New York, USA.

78. Baronzio GF, Cerretta V, Baronzio A, Freitas I, Mapelli M, et al. (2006) Thermo-chemo-Radiotherapy Association: Biological Rationale, preliminary observation on its use on malignant Brain tumors. In: Hyperthermia in Cancer Treatment: a primer. Gianfranco Baronzio and E Dieter Hager (Eds.), Landes and Springer Science+ Business New York, USA.

79. Koutcher JA, Barnett D, Kornblith AB, Cowburn D, Brady TJ, et al. (1990) Relationship of changes in pH and energy status to hypoxic cell fraction and hyperthermia sensitivity. Int J RadiatOncolBiolPhys 18: 1429-1435.

80. Gerweck LE, Seetharaman K (1996) Cellular pH gradient in tumor versus normal tissue: potential exploitation for the treatment of cancer. Cancer Res 56: 1194-1198.

81. Hahn GM (1974) Metabolic aspects of the role of hyperthermia im mammalian cell inactivation and their possible relevance to cancer treatment. Cancer Res 34: 3117-3123.
82. Tanaka H, Kageyama K, Kimura M, Iwamoto SI, Ueno Y, et al. (2006) Promotive effects of hyperthermia on the inhibition of DNA synthesis in ehrlich ascites tumor cells by eicosapentaenoic and docosahexaenoic acids. ExpOncol 28: 203-208

83. Kokura S, Yoshikawa T, Kaneko T, Iinuma S, Nishimura S, et al. (1997) Efficacy of hyperthermia and polyunsaturated fatty acids on experimental carcinoma. Cancer Res 57: 2200-2202.

84. Baronzio GF, Solbiati L, Ierace T, Barzaghi F, Suter F, et al. (1995) Adjuvant therapy with essential fatty acids (EFAs) for primary liver tumors: some hypotheses. Med Hypotheses 44: 149-154.

85. Wong RS (2011) Apoptosis in cancer: from pathogenesis to treatment. J ExpClin Cancer Res 30: 87.

86. Ahmed K, Zaidi SF (2013) Treating cancer with heat: hyperthermia as promising strategy to enhance apoptosis. J Pak Med Assoc 63: 504-508.

87. Ahmed K, Hori T, Yu DY, Wei ZL, Zhao QL, et al. (2008) Hyperthermia chemo-sensitization, chemical thermo-sensitization and apoptosis. Thermal Med 24: 1-12.

88. Liang H, Zhan HJ, Wang BG, Pan Y, Hao XS (2007) Change in expression of apoptosis genes after hyperthermia, chemotherapy and radiotherapy in human colon cancer transplanted into nude mice. World J Gastroenterol 13: 4365-4371.

89. Shellman YG, Howe WR, Miller LA, Goldstein NB, Pacheco TR, et al. (2008) Hyperthermia induces endoplasmic reticulum-mediated apoptosis in melanoma and non-melanoma skin cancer cells. J Invest Dermatol 128: 949-956.

90. Baronzio G, Gramaglia A, Fiorentini G (2006) Hyperthermia and immunity. A brief overview. In Vivo 20: 689-695.

91. Mondovì B, Santoro AS, Strom R, Faiola R, Fanelli AR (1972) Increased immunogenicity of Ehrlich ascites cells after heat treatment. Cancer 30: 885-888.

92. Meniawy TM, Nowak AK, Lake RA (2012) Effect of chemotherapy on the tumor microenvironment and anti-tumor immunity. In: Tumor Ablation, Yona K (Eds.), Springer, Israel.

93. Lee CT, Mace T, Repasky EA (2010) Hypoxia-driven immunosuppression: a new reason to use thermal therapy in the treatment of cancer? Int J Hyperthermia 26: 232-246.

94. Muthana M, Multhoff G, Pockley AG (2010) Tumour infiltrating host cells and their significance for hyperthermia. Int J Hyperthermia 26: 247-255.

95. Baronzio G, Parmar G, Shubina IZH, Cassutti V, Giuli S, et al. (2013) Update on the challenges and recent advances in cancer immunotherapy. ImmunoTargets and Therapy 2: 39-49.

96. Skitzki JJ, Repasky EA, Evans SS (2009) Hyperthermia as an immunotherapy strategy for cancer. CurrOpinInvestig Drugs 10: 550-558.

97. Torigoe T, Tamura Y, Sato N (2009) Heat shock proteins and immunity: application of hyperthermia for immunomodulation. Int J Hyperthermia 25: 610-616

98. Multhoff $\mathrm{G}$ (2009) Activation of natural killer cells by heat shock protein 70. 2002. Int J Hyperthermia 25: 169-175.

99. Zhang HG, Mehta K, Cohen P, Guha C (2008) Hyperthermia on immune regulation: a temperature's story. Cancer Lett 271: 191-204.

100. Frey B, Weiss EM, Rubner Y, Wunderlich R, Ott OJ, et al. (2012) Old and new facts about hyperthermia-induced modulations of the immune system. Int J Hyperthermia 28: 528-542.

101. Fajardo LF, Prionas SD, Kowalski J, Kwan HH (1988) Hyperthermia inhibits angiogenesis. Radiat Res 114: 297-306.

102. Roca C, Primo L, Valdembri D, Cividalli A, Declerck P, et al. (2003) Hyperthermia inhibits angiogenesis by a plasminogen activator inhibitor 1-dependent mechanism. Cancer Res 63: 1500-1507.

103. Horsman MR, Overgaard J (2007) Hyperthermia: a potent enhancer of radiotherapy. ClinOncol (R CollRadiol) 19: 418-426.

104. Schildkopf P, Ott OJ, Frey B, Wadepohl M, Sauer R, et al. (2010) Biological rationales and clinical applications of temperature controlled 
hyperthermia--implications for multimodal cancer treatments. Curr Med Chem 17: 3045-3057.

105. Song CW, Park HJ, Lee CK, Griffin R (2005) Implications of increased tumor blood flow and oxygenation caused by mild temperature hyperthermia in tumor treatment. Int J Hyperthermia 21: 761-767.

106. Vaupel PW, Kelleher DK (2012) Blood flow and associated pathophysiology of uterine cervix cancers: characterisation and relevance for localised hyperthermia. Int J Hyperthermia 28: 518-527.

107. Hokland SL, Nielsen T, Busk M, Horsman MR (2010) Imaging tumour physiology and vasculature to predict and assess response to heat. Int J Hyperthermia 26: 264-272.

108. Harrison DK, Vaupel P (2014) Heterogeneity in tissue oxygenation: from physiological variability in normal tissues to pathophysiological chaos in malignant tumours. AdvExp Med Biol 812: 25-31.

109. Morgan G, Ward R, Barton M (2004) The contribution of cytotoxic chemotherapy to 5 -year survival in adult malignancies. ClinOncol ( $R$ CollRadiol) 16: 549-560.

110. Engelhardt R (1987) Hyperthermia and drugs. Recent Results Cancer Res 104: 136-203.

111. Dahl O (1988) Interaction of hyperthermia and chemotherapy. Recent Results Cancer Res 107: 157-169.

112. Hahn GM (1979) Potential for therapy of drugs and hyperthermia. Cancer Res 39: 2264-2268.

113. Urano M, Kuroda M, Nishimura Y (1999) For the clinical application of thermochemotherapy given at mild temperatures. Int J Hyperthermia 15: 79-107.

114. Issels RD (1993) Hyperthermia and thermochemotherapy. Cancer Treat Res 67: 143-160.

115. Dietzel F (1983) Basic principles in hyperthermic tumor therapy. Recent Results Cancer Res 86: 177-190.

116. Overgaard J (1989) The current and potential role of hyperthermia in radiotherapy. Int J Radiat Oncol Biol Phys 16: 535-549.

117. Hildebrandt B, Wust P, Ahlers O, Dieing A, Sreenivasa G, et al. (2002) The cellular and molecular basis of hyperthermia. Crit Rev OncolHematol 43: 33-56.

118. Teicher BA, Herman TS, Holden SA (1988) Combined modality therapy with bleomycin, hyperthermia, and radiation. Cancer Res 48: 6291-6297.

119. Herman TS, Teicher BA, Jochelson M, Clark J, Svensson G, et al. (1988) Rationale for use of local hyperthermia with radiation therapy and selected anticancer drugs in locally advanced human malignancies. Int J Hyperthermia 4: 143-158.

120. Weber J (2010) Immune checkpoint proteins: a new therapeutic paradigm for cancer--preclinical background: CTLA-4 and PD-1 blockade. SeminOncol 37: 430-439.

121. Falk MH, Issels RD (2001) Hyperthermia in oncology. Int J Hyperthermia 17: 1-18.

122. P Gabriele and C Roca (2006) Results of hyperthermia alone or with radiation therapy and/or chemotherapy. In: Hyperthermia in Cancer Tratment: A primer. Gianfranco Baronzio and E Dieter Hager (Eds.), Landes and Springer Science+ Business, New York, USA.

123. Szasz A, Szasz N, Szasz O (2010) Oncothermia-Principles and Practices. Springer Verlag, Heidelberg.
124. Kim JH, Hahn EW, Ahmed SA (1982) Combination hyperthermia and radiation therapy for malignant melanoma. Cancer 50: 478-482.

125. Perez CA, Pajak T, Emami B, Hornback NB, Tupchong L, et al. (1991) Randomized phase III study comparing irradiation and hyperthermia with irradiation alone in superficial measurable tumors. Am J ClinOncol 14: 133-141.

126. Vernon CC, Hand JW, Field SB, Machin D, Whaley JB, et al. (1996) Radiotherapy with or without hyperthermia in the treatment of superficial localized breast cancer: results from five randomized controlled trials. Int J RadiatOncolBiolPhys 35: 731-744.

127. Van Der Zee J, Gonzalez Gonzalez D, Van Rhoon GC, Van Dijk JD, Van Putten WL, et al. (2000) Comparison Of Radiotherapy Alone With Radiotherapy Plus Hyperthermia In Locally Advanced Pelvic Tumours: A Prospective, Randomised, Multicentre Trial. Dutch Deep Hyperthermia Group. Lancet 355: 1119-1125.

128. Sneed PK, Stauffer PR, Mcdermott MW, Diederich CJ, Lamborn KR, et al. (1998) Survival benefit of hyperthermia in a prospective randomized trial of brachytherapy boost (hyperthermia for glioblastomamultiforme. Int J Radiat Oncol Biol Phys, 40: 287-295.

129. Sugimachi K, Kuwano H, Ide H, Toge T, Saku M, et al. (1994) Chemotherapy combined with or without hyperthermia for patients with oesophageal carcinoma: a prospective randomized trial. Int J Hyperthermia 10: 485-493.

130. Ohno S, Tomoda M, Tomisaki S, Kitamura K, Mori M, et al. (1997) Improved surgical results after combining preoperative hyperthermia with chemotherapy and radiotherapy for patients with carcinoma of the rectum. Dis Colon Rectum 40: 401-406.

131. Hager ED, Dziambor H, Höhmann D, Gallenbeck D, Stephan M, et al. (1999) Deep hyperthermia with radiofrequencies in patients with liver metastases from colorectal cancer. Anticancer Res 19: 3403-3408.

132. Hamazoe R, Maeta M, Murakami A, Yamashiro H, Kaibara N (1991) Heating efficiency of radiofrequency capacitive hyperthermia for treatment of deep-seated tumors in the peritoneal cavity. J SurgOncol 48: 176-179.

133. Fiorentini G, Giovanis P, Rossi S, Dentico P, Paola R, et al. (2006) A phase II clinical study on relapsed malignant gliomas treated with electro-hyperthermia. In Vivo 20: 721-724.

134. Sahinbas H, Groenemeyer D, Boecher E, Szasz A (2007) Retrospective clinical study of adjuvant electrohyperthermia treatment for advanced braingliomas. German Journal of Oncology, 39: 154-160.

135. Aydin H (2003) Strahlen-Hyperthermiebei Lebermetastasen und bei therapieresistenten Knochenmetastasen. Hyperthermia Symposium, 25-26 October, Cologne, Germany.

136. Ferrari VD, De Ponti S, Valcamonico F, Amoroso V, Grisanti S, et al. (2007) Deep electro-hyperthermia (EHY) with or without thermo-active agents in patients with advanced hepatic cell carcinoma: phase II study. J ClinOncol 25: 15168.

137. Pang C (2010) Clinical Research on Integrative Treatment of Colon Carcinoma with Oncothermia and Clifford TCM Immune Booster. 1st International Oncothermia Symposium, 22-23 November, Cologne, Germany.

138. Dewhirst MW (1994) Future directions in hyperthermia biology. Int J Hyperthermia 10: 339-345. 